\title{
Presence of Vasoactive Intestinal Peptide Receptor in the Hen Hypothalamus
}

\author{
Sylvia Maet GONZALES, Mitsuo KAWASHIMA*, Michiharu KAMIYOSHI*, \\ KATUHIDE TANAKA AND KeNJI ICHINOE
}

The Department of Zootechnical Science, Tokyo University of Agriculture, Tokyo 156, and

*The Department of Animal Science and Technology, Gifu University, Gifu 501-11, Japan

\begin{abstract}
Radioligand assays of the membrane fraction of hen hypothalamic tissues involving the preoptic (HPOA) or median eminence (HMEA) areas revealed the presence of a specific binding component to chicken vasoactive intestinal peptide (cVIP) having properties of a receptor. The equilibrium dissociation constant $\left(\mathrm{K}_{\mathrm{d}}\right)$ was $0.70 \pm 0.07 \mathrm{nM}$ (Mean $\left.\pm \mathrm{SEM} ; \mathrm{N}=5\right)$ in HPOA and $1.02 \pm 0.15 \mathrm{nM}(\mathrm{N}=5)$ in HMEA as estimated by Scatchard analysis of saturation studies, and was $0.91 \pm 0.11 \mathrm{nM}(\mathrm{N}=3)(\mathrm{HPOA})$ and 1.25 $\pm 0.09 \mathrm{nM}(\mathrm{N}=3)(\mathrm{HMEA})$ as determined by a kinetic analysis. The maximum binding capacity $\left(\mathrm{B}_{\max }\right)$ obtained by Scatchard analysis was $167 \pm 19 \mathrm{fmol} / \mathrm{mg}$ protein $(\mathrm{N}=5)$ (HPOA) and $133 \pm 17 \mathrm{fmol} / \mathrm{mg}$ protein $(\mathrm{N}=5)$ (HMEA). The $\mathrm{K}_{\mathrm{d}}$ and $\mathrm{B}_{\max }$ values obtained by Scatchard analysis were similar in the two areas of the hypothalamus and in both laying and nonlaying hens. Administration of cVIP in vivo caused a decrease in specific cVIP binding. These results suggest the presence of a VIP receptor in the hen hypothalamus.
\end{abstract}

Key words: Vasoactive intestinal peptide receptor, Radioligand assay, Scatchard analyses, Hypothalamus, Laying hen

(Endocrine Journal 42: 179-186, 1995)

VASOACTIVE intestinal peptide (VIP) is composed of 28 amino-acid residues and was first isolated from porcine small intestine [1]. Chicken VIP (cVIP) is different in its amino acid sequence from that of mammalian VIP at positions 11, 13, 26 , and 28 , although the total number of amino acid residues is the same [2]. Abundant VIP immunoreactive neurons are found in the hypothalamus of the quail [3], bantam [4], pigeon [5], and turkey [6] with axons that extend to the external layer of the median eminence, suggesting physiological relevance in neuroendocrine regulation. The presence of VIP receptors in the brain of guinea pigs [7] and rats [8, 9] has been reported,

Received: June 13, 1994

Accepted: November 22, 1994

Correspondence to: Dr. Katuhide TANAKA, Department of Zootechnical Science, Tokyo University of Agriculture, 1-1-1 Sakuragaoka, Setagaya, Tokyo 156, Japan but their occurrence in the avian brain has not been demonstrated. This study was performed to demonstrate the presence of VIP receptors in the hypothalamic tissues of the chicken.

\section{Materials and Methods}

\section{Animals and tissues}

White Leghorn hens (18 months of age; 1.7 to $2.2 \mathrm{~kg}$ body weight) laying three to six sequential eggs with a 1-day pause between sequences, for more than 2 weeks before the experiment, were used as laying hens. Hens that had not laid an egg for 1 week before the experiments were also used as nonlaying hens. The birds used were obtained from a flock of birds kept in individual cages under $14 \mathrm{~h}$ (0500 to $1900 \mathrm{~h})$ light/day with feed and water provided ad libitum. The laying hens 
were killed by decapitation at $1000 \mathrm{~h}$ without regard to the time of ovulation ( 30 birds in each sample), and the nonlaying hens were killed at the same hour of the day (30 birds in each sample) for Experiment 1. In the nonlaying hens necropsied, the weights of the ovary and oviduct were less than 8.5 and $14.3 \mathrm{~g}$, respectively. The plasma concentrations of progesterone $\left(\mathrm{P}_{4}\right)$, estradiol- $17 \beta\left(\mathrm{E}_{2}\right)$, and testosterone (T) were less than $108 \mathrm{pg} / \mathrm{ml}\left(\mathrm{P}_{4}\right)$, $81 \mathrm{pg} / \mathrm{ml}\left(\mathrm{E}_{2}\right)$, and $82 \mathrm{pg} / \mathrm{ml}(\mathrm{T})$, respectively, as determined by RIA [10]. For Experiment 2, the nonlaying hens ( 7 birds/sample in each group) received a single iv injection of chicken VIP (cVIP; 5 $\mu \mathrm{g} / 0.5 \mathrm{~m} l$ saline/bird) or vehicle $(0.5 \mathrm{ml}$ of saline/ bird) at $1000 \mathrm{~h}$ and were killed 5, 10, 30, 60, and $120 \mathrm{~min}$ after the injection. From all of these birds, the tissues of hypothalamus were excised, weighed, and pooled. These involved the preoptic area (HPOA, the tissue just anterior to the optic chiasma and posterior to the tractus septomesencephalicus, with an approximate width of 1 $\mathrm{mm}$ bilaterally from the midline and to an approximate depth of $3 \mathrm{~mm}$, weighing 26 to $31 \mathrm{mg}$ ), and median eminence area (HMEA; the tissue just posterior to the occulomotor nerve, with an approximate width of $1 \mathrm{~mm}$ bilaterally from the midline and with an approximate depth of $3 \mathrm{~mm}$ weighing 23 to $26 \mathrm{mg}$ ).

\section{Preparation of membrane fraction}

The sucrose gradient centrifugation method [11] was adopted for the preparation of membrane fractions with Tris buffer containing $0.25 \mathrm{mM}$ sucrose. All steps were performed at $4{ }^{\circ} \mathrm{C}$. The tissues of the hypothalamus were homogenized in $20 \mathrm{vol} /$ wt Tris-sucrose buffer (TS; $25 \mathrm{mM}$ Tris- $\mathrm{HCl}, 0.25$ $\mathrm{M}$ sucrose, $\mathrm{pH}$ 7.4) in a Potter-Elvehjem glass teflon homogenizer. The homogenate was centrifuged at $1,000 \times \mathrm{g}$ for $10 \mathrm{~min}$, and the supernatant was obtained. The precipitate was resuspended in the same buffer, rehomogenized, and centrifuged again. The supernatants were centrifuged at $12,000 \times \mathrm{g}$ for $20 \mathrm{~min}$. The precipitate was suspended in TS buffer and was fractionated at $100,000 \times \mathrm{g}$ for $2 \mathrm{~h}$ in the RPS-25 swinging rotor of a Hitachi 65P ultracentrifuge (Hitachi Koki Co., Ibaragi), with a discontinuous sucrose density gradient consisting of $0.8,1.0$, and $1.2 \mathrm{M}$ sucrose in Tris buffer ( $25 \mathrm{mM}$ Tris- $\mathrm{HCl}, \mathrm{pH}$ 7.4). The interface fraction between 1.0 and $1.2 \mathrm{M}$ sucrose was obtained and suspended in $10 \mathrm{vol} / \mathrm{vol}$ Tris- $\mathrm{MgCl}_{2}-$ Bacitracin buffer (TMB; $25 \mathrm{mM}$ Tris- $\mathrm{HCl}, 2 \mathrm{mM}$ $\mathrm{MgCl}_{2}, 0.2 \mathrm{mM}$ bacitracin, $\mathrm{pH}$ 7.4). The suspension was centrifuged at $12,000 \times \mathrm{g}$ for $20 \mathrm{~min}$. The precipitate was resuspended and centrifuged again, and the precipitate was suspended in TMB buffer and used as a membrane fraction. The protein concentration of the fraction was measured [12] with BSA (Fraction V; Sigma Chem. Co., USA) as a standard.

\section{Radioiodination of chicken vasoactive intestinal peptide (cVIP)}

The cVIP was labeled with Na-125I (Amersham International Plc, UK) by the iodogen method [10] and chromatographed on a $1 \times 100 \mathrm{~cm}$ column of Sephadex G-25 (superfine type; Pharmacia LKB, Sweden) eluted with $0.1 \mathrm{M}$ acetic acid containing $0.1 \%$ BSA. Two radioactive peaks prior to the free ${ }^{125}$ I peak were obtained, and the two peaks were clearly separated. The first peak bound well to the membrane fraction, and the percentage of nonspecific binding to total binding was less than $20 \%$, but the second peak bound poorly. The specific activity of ${ }^{125} \mathrm{I}-\mathrm{cVIP}$, expressed as monoiodo cVIP, was calculated to be 480 to $670 \mathrm{Ci} / \mathrm{mmol}$ assuming complete recovery of the peptide. All experiments were performed within 40 days after radioiodination.

\section{Binding assay}

The specific binding of ${ }^{125} \mathrm{I}-\mathrm{cVIP}$ was measured [11] with modifications. The diluent used was TMB buffer containing $0.1 \%$ BSA and $1 \mathrm{mM}$ phenylmethylsulfonyl fluoride (Sigma Chem. Co., USA). Aliquots of the membrane fraction ( $50 \mu \mathrm{g}$ protein/ tube) were incubated at $30{ }^{\circ} \mathrm{C}$ for $4 \mathrm{~h}$ with ${ }^{125} \mathrm{I}-$ $\operatorname{cVIP}(0.1$ to $3.4 \mathrm{nM})$ in the absence (total binding) or presence (nonspecific binding) of a 100-fold molar excess of unlabeled cVIP in a total volume of $200 \mu \mathrm{l}$. For binding specificity, samples were incubated with ${ }^{125} \mathrm{I}-\mathrm{cVIP}(0.8 \mathrm{nM})$ in the absence or presence of various molar excesses $(0.8,8,80,800$ or $8,000 \mathrm{nM}$ ) of unlabeled competitors. The unlabeled competitors for binding specificity were cVIP (Applied Biosystem, USA), mammalian VIP (mVIP; Peninsula Lab., USA), chicken secretin (Secretin; Peninsula Lab., USA), rat peptide histidine isoleucine (PHI; Peninsula Lab., USA), human glucagon 
(Glucagon; Peninsula Lab., USA) and rat growth hormone releasing factor (GRF; Peninsula Lab., USA). After the incubation, $2 \mathrm{ml}$ of ice-cold TMB buffer was added. Bound and free radioligands were separated by rapid filtration under vacuum through glass microfiber filters (GF/B type; Advance Toyo Co., Tokyo) that were presoaked overnight in $0.5 \%$ polyethylenimine (Sigma Chem. Co., USA) to reduce the background value [13]. The filters were washed twice with $2 \mathrm{ml}$ TMB buffer and radioactivity was measured in a gamma counter (Cobra Model B5002; Packard Instrument Co., USA), with a counting efficiency of 65 to $82 \%$. Specific binding was obtained by subtracting nonspecific binding from total binding, and expressed as moles per milligram protein. The equilibrium dissociation constant $\left(\mathrm{K}_{\mathrm{d}}\right)$ and the maximum binding capacity $\left(\mathrm{B}_{\max }\right)$ were determined by Scatchard analysis [14].

Preliminary experiments examined the relationship of the specific ${ }^{125} \mathrm{I}-\mathrm{cVIP}$ binding to the incubation period ( $15 \mathrm{~min}$ to $8 \mathrm{~h}$ ) and to the protein concentration ( 12.5 to $100 \mu \mathrm{g} /$ tube) in the membrane fractions of HPOA and HMEA of laying hens. Specific ${ }^{125} \mathrm{I}-\mathrm{cVIP}$ binding was found to increase during the first $2 \mathrm{~h}$ of incubation period and to remain stable until $8 \mathrm{~h}$. Specific ${ }^{125} \mathrm{I}-\mathrm{cVIP}$ binding increased linearly with the increase in the protein concentration from 12.5 to $100 \mu \mathrm{g} /$ tube.

\section{Statistical analyses}

Kinetic data were analyzed [15] by means of pseudo-first-order conditions to estimate the association rate constant $\left(\mathrm{K}_{+1}\right)$ and by the addition of a large excess of unlabeled ligand to estimate the dissociation rate constant $\left(\mathrm{K}_{-1}\right)$.

The data, except for Figs. 2 and 3, were expressed as the mean \pm SEM for three to five separate pools of samples. For comparisons among more than two groups, the data were analyzed by one-way ANOVA [16]. When significant $(P<0.05)$ effects were found, Tukey's multiple range test was used to separate means in Table 1 [16], and Dunnett's test was used to assess the significance of difference from ' 0 min' value in Fig. 4 (Super ANOVA version 1.1; Abacus Concepts, Inc., USA). Probability $(P)$ values of less than 0.05 were considered significant.

\section{Results}

\section{Kinetic analysis of radioiodinated cVIP}

Specific binding of ${ }^{125} \mathrm{I}-\mathrm{cVIP}$ in the membrane fraction of HPOA and HMEA of laying hens reached a steady state at $2 \mathrm{~h}$ and was stable for up to $8 \mathrm{~h}$ (Fig. 1). A decrease in specific ${ }^{125} \mathrm{I}-\mathrm{cVIP}$ binding occurred upon adding a large excess of unlabeled cVIP (Fig. 1). The binding of ${ }^{125} \mathrm{I}-\mathrm{cVIP}$ to HPOA and HMEA was reversible and time dependent. The association rate constant $\left(\mathrm{K}_{+1}\right)$ was $0.021 \pm 0.002 \mathrm{nM}^{-1} \mathrm{~min}^{-1}$ (mean $\pm \mathrm{SEM} ; \mathrm{N}=3$ ) in HPOA and $0.012 \pm 0.001 \mathrm{nM}^{-1} \min ^{-1}(\mathrm{~N}=3)$ in HMEA, respectively. Specific ${ }^{125} \mathrm{I}-\mathrm{cVIP}$ binding was reversed $\left(t_{1 / 2}=37.1 \pm 1.5 \min (\mathrm{N}=3)\right.$ in HPOA and

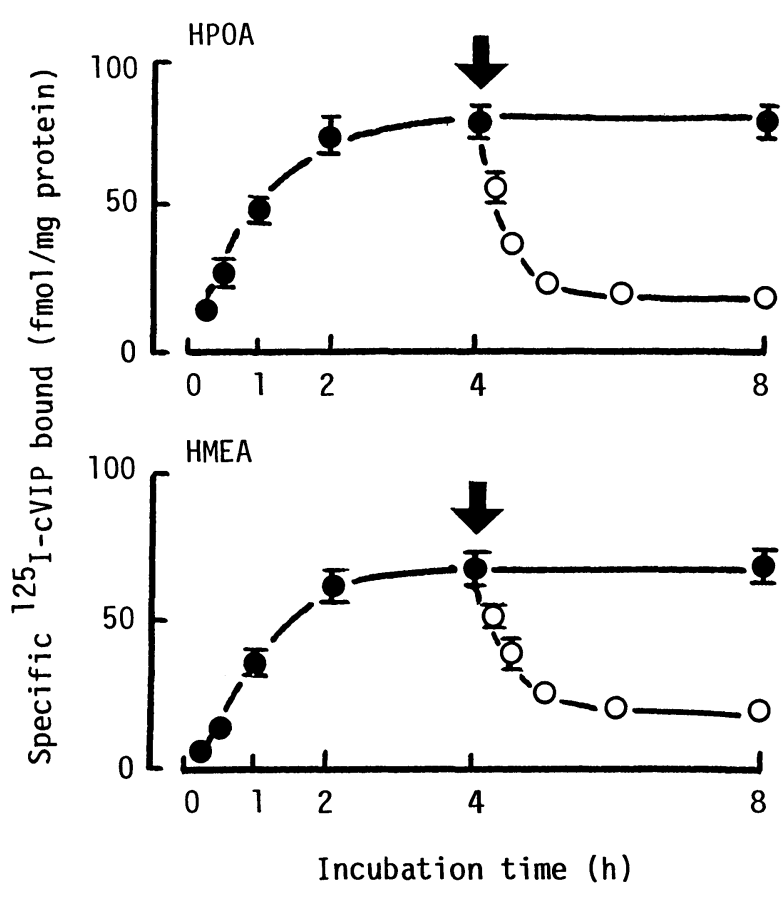

Fig. 1. Time-course for the association (๑) and dissociation (O) of ${ }^{125}$ I-chicken vasoactive intestinal peptide (cVIP) in the membrane fractions of hypothalamus involving the preoptic (HPOA) and median eminence (HMEA) areas of laying hens. Samples (50 $\mu$ g protein/tube) were incubated at $30^{\circ} \mathrm{C}$ for various times with ${ }^{125} \mathrm{I}-\mathrm{cVIP}(0.8 \mathrm{nM})$ in the absence or presence of a 100 -fold molar excess of unlabeled cVIP, and specific ${ }^{125} \mathrm{I}-\mathrm{cVIP}$ binding was measured. Specific ${ }^{125}$ I-cVIP binding decreased following the addition of $1 \mu \mathrm{M}$ unlabeled cVIP (arrow). Each point represents the mean \pm SEM for three separate pools of samples. Standard errors not shown fall within the points as drawn. 
$t_{1 / 2}=45.1 \pm 1.1 \min (\mathrm{N}=3)$ in HMEA, respectively) by adding a large excess of unlabeled cVIP. The rate constant for dissociation $\left(\mathrm{K}_{-1}\right)$ determined from the pseudo-first-order equation was $0.019 \pm$ $0.0007 \mathrm{~min}^{-1}$ in HPOA and $0.015 \pm 0.0004 \mathrm{~min}^{-1}$ in HMEA, respectively. The kinetic dissociation constant $\left(\mathrm{K}_{\mathrm{d}}\right)$ for ${ }^{125} \mathrm{I}-\mathrm{cVIP}$ calculated from the ratio $\mathrm{K}_{-1} / \mathrm{K}_{+1}$ was $0.91 \pm 0.11 \mathrm{nM}(\mathrm{N}=3)$ in HPOA and $1.25 \pm 0.09 \mathrm{nM}(\mathrm{N}=3)$ in HMEA, respectively.

\section{Binding specificity}

${ }^{125} \mathrm{I}-\mathrm{cVIP}$ binding in the membrane fraction of HPOA and HMEA of laying hens was greatly reduced by the presence of a 100 -fold molar excess of unlabeled cVIP or mVIP, but was little affected by the presence of an equivalent molar concentration of unlabeled GRF, PHI, secretin or glucagon (Fig. 2). GRF, PHI and Secretin reduced the binding a little ( 20 to $40 \%$ ) when a 10,000 -fold molar excess was used.

\section{Binding affinity and capacity}

Specific ${ }^{125} \mathrm{I}-\mathrm{cVIP}$ binding in the membrane fraction of HPOA and HMEA of laying hens increased when increasing amounts of ${ }^{125}$ I-cVIP were added (i.e., when the amount of free ${ }^{125} \mathrm{I}-\mathrm{cVIP}$ was increased), and was saturable at about $1.5 \mathrm{nM}$ (Fig. 3 ). Scatchard analysis revealed a linear relationship between the amount of ${ }^{125}$ I-cVIP specifically bound, and the ratio of ${ }^{125} \mathrm{I}-\mathrm{cVIP}$ specifically bound to free ${ }^{125} \mathrm{I}-\mathrm{cVIP}$ (B/F) (Fig. 3), indicating a single class of binding sites. The $\mathrm{K}_{\mathrm{d}}, \mathrm{B}_{\max }$ value and coefficient of correlation $(r)$ between B/F and ${ }^{125} \mathrm{I}-\mathrm{cVIP}$ specifically bound (calculated from the data in Fig. 3) were $0.67 \mathrm{nM}\left(\mathrm{K}_{\mathrm{d}}\right), 205 \mathrm{fmol} / \mathrm{mg}$ protein $\left(\mathrm{B}_{\max }\right)$ and $-0.979(r)$ in HPOA and $1.08 \mathrm{nM}\left(\mathrm{K}_{\mathrm{d}}\right), 176$ $\mathrm{fmol} / \mathrm{mg}$ protein $\left(\mathrm{B}_{\max }\right)$ and $-0.983(r)$ in HMEA, respectively.

Table 1 lists the average $K_{d}$ and $B_{\max }$ values determined by Scatchard analysis of specific ${ }^{125} \mathrm{I}-\mathrm{cVIP}$ binding in the membrane fractions of HPOA and HMEA obtained from five separate pooled sam-

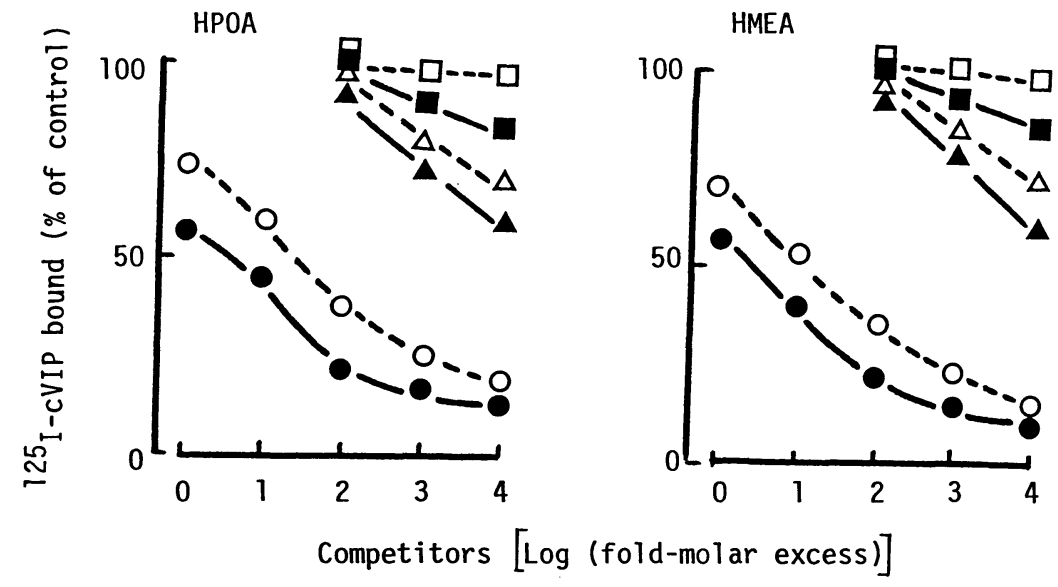

Fig. 2. Competition for ${ }^{125} \mathrm{I}$-chicken vasoactive intestinal peptide (cVIP) binding in membrane fractions of hypothalamus involving the preoptic (HPOA) and median eminence (HMEA) areas of laying hens. Samples ( $50 \mu \mathrm{g}$ protein/tube) were incubated at $30^{\circ} \mathrm{C}$ for $4 \mathrm{~h}$ with ${ }^{125} \mathrm{I}-\mathrm{cVIP}(0.8$ $\mathrm{nM}$ ) in the absence (control) or presence of various-fold molar excess $(0=0.8 \mathrm{nM} ; 1=8 \mathrm{nM} ; 2=80 \mathrm{nM} ; 3=800 \mathrm{nM} ; 4=8,000 \mathrm{nM})$ of unlabeled competitors, and ${ }^{125} \mathrm{I}-\mathrm{cVIP}$ binding was measured. The ${ }^{125} \mathrm{I}-\mathrm{cVIP}$ binding value in the control was $84 \mathrm{fmol} / \mathrm{mg}$ protein for HPOA and 65 $\mathrm{fmol} / \mathrm{mg}$ protein for HMEA, respectively. Each point represents the mean for two separate pooled samples. The competitors tested were: cVIP $(\circlearrowleft)$, mammalian VIP (mVIP; $\bigcirc)$, rat growth hormone releasing factor (GRF; $\mathbf{\Delta})$, rat peptide histidine isoleucine (PHI; $\triangle$ ), chicken secretin ( $\square$ ), and human glucagon $(\square)$. 

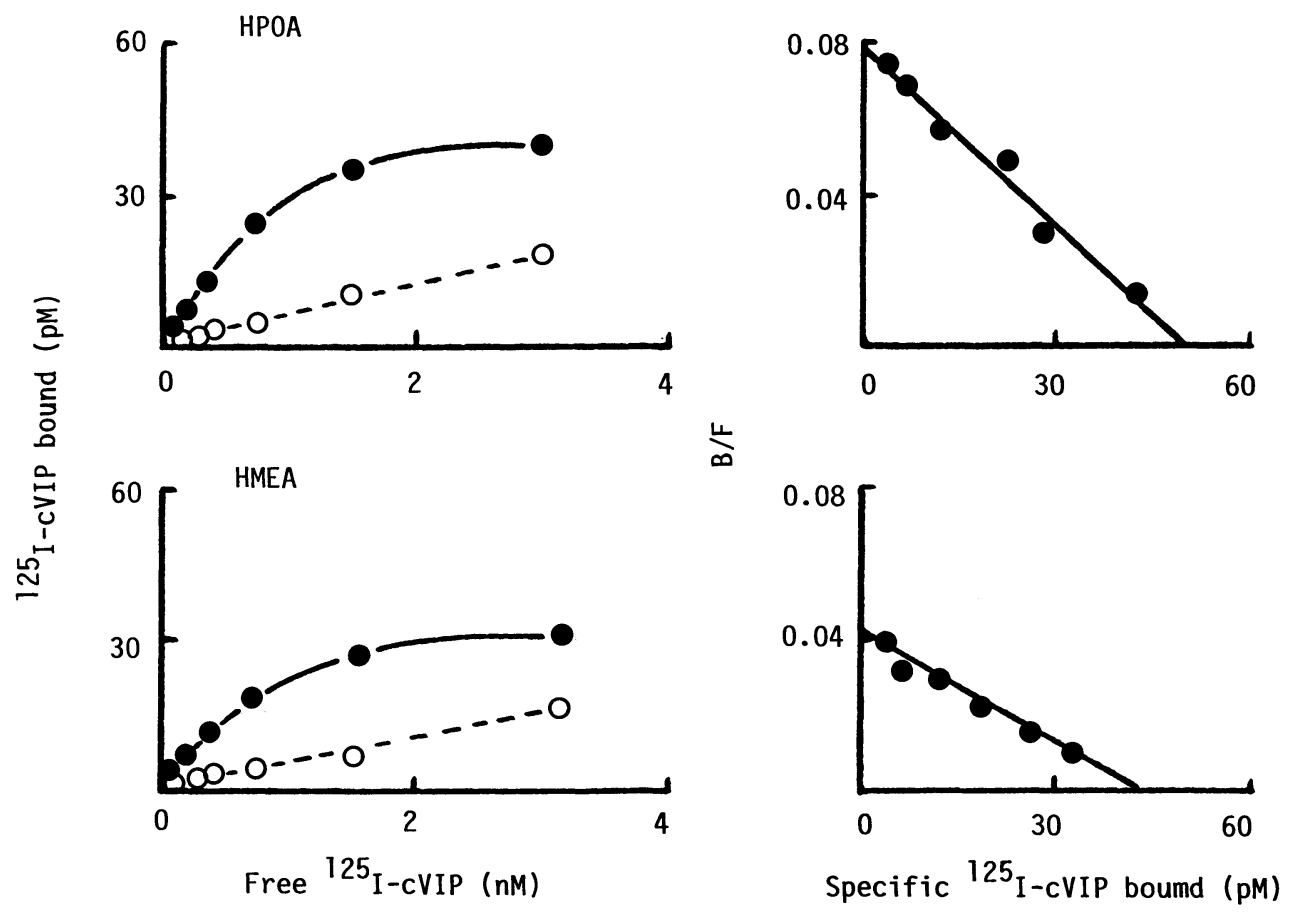

Fig. 3. Saturation curves and Scatchard plots for specific ${ }^{125}$ I-chicken vasoactive intestinal peptide (cVIP) binding in membrane fractions of hypothalamus involving the preoptic (HPOA) and median eminence (HMEA) areas of a single pool of laying hens. Samples (50 $\mu \mathrm{g}$ protein/tube) were incubated at $30^{\circ} \mathrm{C}$ for $4 \mathrm{~h}$ with various concentrations $(0.1$ to $3.4 \mathrm{nM})$ in the absence or presence of a 100 -fold molar excess of unlabeled cVIP, and ${ }^{125} \mathrm{I}-\mathrm{cVIP}$ binding was measured. Each point represents the mean of duplicate determinations on one pooled sample. $B=$ bound; $F=$ free.

- specific binding; $\bigcirc-\bigcirc$, nonspecific binding.

Table 1. The equilibrium dissociation constant $\left(\mathrm{K}_{\mathrm{d}}\right)$ and maximum binding capacity $\left(\mathrm{B}_{\max }\right)$ of the ${ }^{125} \mathrm{I}-\mathrm{cVIP}$ ) binding component of membrane fractions of hypothalamus involving the preoptic (HPOA) and median eminence (HMEA) areas of the laying (L) and nonlaying (NL) hens

\begin{tabular}{lccc}
\hline Tissue & Hen & $\begin{array}{c}\left.\mathrm{K}_{\mathrm{d}} \mathrm{b}\right) \\
(\mathrm{nM})\end{array}$ & $\begin{array}{c}\left.\mathrm{B}_{\max }{ }^{\mathrm{b}}\right) \\
(\mathrm{fmol} / \mathrm{mg} \text { protein })\end{array}$ \\
\hline HPOA & $\mathrm{L}$ & $\left.0.70 \pm 0.07^{\mathrm{c}}\right)$ & $167 \pm 19$ \\
& $\mathrm{NL}$ & $0.89 \pm 0.11$ & $197 \pm 18$ \\
HMEA & $\mathrm{L}$ & $1.02 \pm 0.15$ & $133 \pm 17$ \\
& $\mathrm{NL}$ & $0.93 \pm 0.17$ & $147 \pm 14$ \\
\hline
\end{tabular}

a) ${ }^{125} \mathrm{I}-\mathrm{cVIP}=$ radioiodinated chicken vasoactive intestinal peptide. b) Calculated by Scatchard (1949) analysis. c) Mean \pm SEM for five separate pools of samples. Means in the same column are not significantly different $(P>0.05)$ by Tukey's multiple range test. ples. The $K_{d}$ and $B_{\max }$ values were similar for both HPOA and HMEA, and for laying and nonlaying hens.

\section{Changes following in vivo administration of cVIP}

Specific binding of ${ }^{125} \mathrm{I}-\mathrm{cVIP}$ in the membrane fraction of the HPOA and HMEA of nonlaying hens showed a decrease 5 and $10 \mathrm{~min}$ after iv injection of cVIP (Fig. 4). No significant difference was observed at any time after the injection of vehicle.

\section{Discussion}

The VIP-binding component in membrane fractions of HPOA and HMEA of the laying hens were found to possess characteristic properties of a receptor, such as reversible binding, binding specificity, high affinity and limited capacity. $K_{d}$ values (indicating the degree of binding affinity) 
obtained from the kinetic analysis were $0.91 \pm 0.11$ $\mathrm{nM}$ in HPOA and $1.25 \pm 0.09 \mathrm{nM}$ in HMEA of laying hens, which were in close agreement with the values $0.67 \pm 0.07 \mathrm{nM}$ (HPOA) and $1.02 \pm 0.15$ nM (HMEA), obtained from saturation studies. The binding component of these hypothalamic tissues was regarded as having a single class of binding site. These results are similar to those obtained in competitive binding studies on the rat brain membrane [8], where the VIP receptor has a single class of binding sites with a $\mathrm{K}_{\mathrm{d}}$ of $1.0 \mathrm{nM}$, and also on the cat renal outer medulla membrane [17] or the chicken pineal membrane [18] in which the binding site is a single class with a $\mathrm{K}_{\mathrm{d}}$ of $0.83 \mathrm{nM}$ or $0.98 \mathrm{nM}$. The results are different, however, from

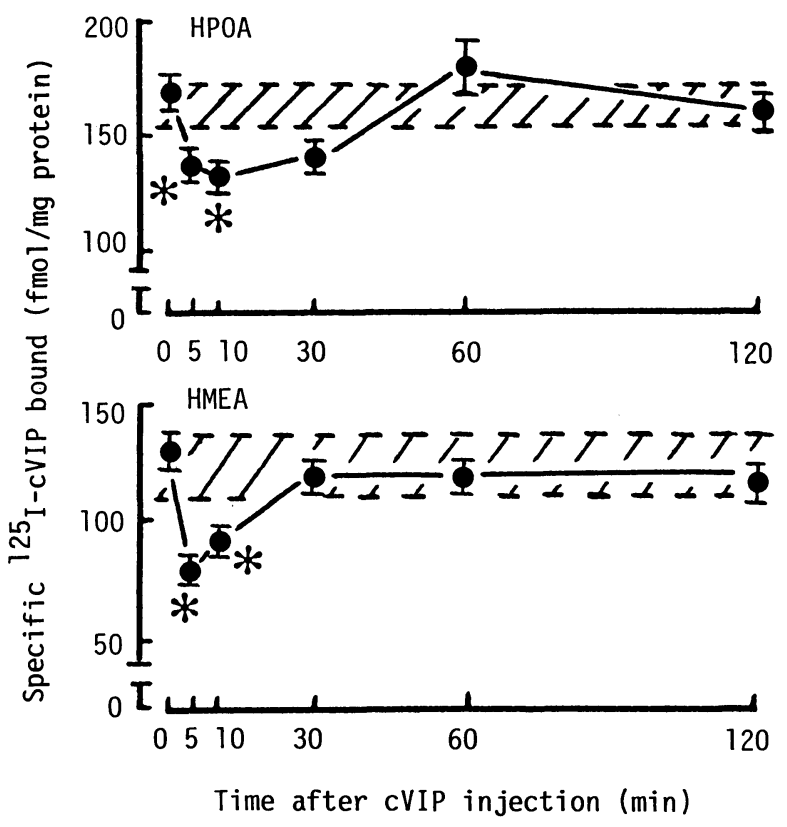

Fig. 4. Specific ${ }^{125} \mathrm{I}$-chicken vasoactive intestinal peptide (cVIP) binding in membrane fractions of hypothalamus involving the preoptic (HPOA) and median eminence (HMEA) areas after an iv injection of cVIP (5 $\mu \mathrm{g} / 0.5 \mathrm{~m} /$ saline/bird). Samples $(50 \mu \mathrm{g}$ protein/tube) obtained from nonlaying hens after the injection of cVIP $(\bullet)$ or saline (control) were incubated at $30^{\circ} \mathrm{C}$ for $4 \mathrm{~h}$ with $2 \mathrm{nM}{ }^{125} \mathrm{I}-\mathrm{cVIP}$ in the absence or presence of a 100-fold molar excess of unlabeled cVIP, and specific ${ }^{125} \mathrm{I}-\mathrm{cVIP}$ binding was measured. The shaded area represents the range determined by the maximum and the minimum value of SEM of control values. Each point represents the mean \pm SEM for four separate pools of samples. Asterisks indicate that the value is significantly different from ' $0 \mathrm{~min}^{\prime}$ value by Dunnett's test $\left({ }^{*} P<0.05\right)$. those obtained by similar competitive binding studies on guinea pig [7] and rat [9] brain, turkey [19] and rat [20] pituitary, rat pineal [21], rat uterus [22], feline kidney [17], chicken thymus and bursa of fabricius [23], and rat blood vessels [11]. In these tissues, the binding component possesses two distinct binding sites of low and high affinity. The discrepancy may be due to the difference in the tissues, and animals used.

In turkey pituitary [19], the higher affinity site is at the level of $10^{-12} \mathrm{M}$, and the lower affinity site is at the level of $10^{-10}$ to $10^{-9} \mathrm{M}$. The lower affinity site in the turkey pituitary is at the same level as found in the present study. In the rat pituitary, two binding sites are also reported [20]. The higher affinity site is at the level of $10^{-10} \mathrm{M}$ and is thought to be the specific receptor for VIP, because the lower affinity site, which is at the level of $10^{-8}$ $M$, is regarded as not having the binding specificity for VIP, i.e., it binds not only to VIP but also to other peptides of similar chemical structure such as secretin and glucagon [24]. One of the physiological actions of VIP in mammals and birds is known to stimulate prolactin (PRL) release from the pituitary. The stimulation of PRL release is exerted at the level of $10^{-9} \mathrm{M}\left(\mathrm{ED}_{50}\right)$ in the rat pituitary [20] and at the level of $10^{-10}$ to $10^{-8} \mathrm{M}$ in the turkey pituitary [25]. The affinity of the binding site in the hen hypothalamus in the present study is at the level of $10^{-10}$ to $10^{-9} \mathrm{M}$. It may be likely that the binding component found in the present study is a physiologically significant receptor for VIP. In mammals, the primary structure of the Nterminus 28 residues of pituitary adenylate cyclase-activating polypeptide 38 (PACAP 38) shows a $68 \%$ amino acid sequence homology with mammalian VIP [26]. The PACAP specific receptor does not show competition with mammalian VIP [27], and is postulated to be obviously distinct from VIP receptor [28].

The $B_{\max }$ values obtained in the present study are of a similar order (expressed as $\mathrm{fmol} / \mathrm{mg}$ protein) to those reported for the high affinity binding site of the VIP receptor in various VIP-responsive tissues of mammals [17, 20, 22], including the rat brain synaptosomes [9].

Both $K_{d}$ and $B_{\max }$ values in HPOA and HMEA were similar in both laying and nonlaying hens, and therefore the possibility that ovarian function affects the binding affinity and capacity of the VIP 
binding component of the hypothalamus is unlikely. A marked decrease in specific binding was found in both HPOA and HMEA after the administration of cVIP in vivo. This may result from a reduction in the receptor. The occurrence of reduction in or internalization of the VIP receptor has been observed in the human adenocarcinoma cell line [29].
The presence of VIP receptor in the hypothalamic tissues of the hen suggests that VIP may play a role in hypothalamic function of the hen. That VIP in vivo causes neuronal excitation in the brain of mammals [30] and activation of adenylate cyclase [31] has been reported, but the physiological function of VIP in the hen hypothalamus is not yet known.

\section{References}

1. Said SI, Mutt V (1970) Polypeptide with broad biological activity: Isolation and small intestine. Science 169: 1217-1134.

2. Nisson A (1975) Structure of the vasoactive intestinal octacosapeptide from chicken intestine. The amino acid sequence. Fed Exp Biol Sci Lett 60: 322326.

3. Yamada S, Mikami S (1982) Immunohistochemical localization of vasoactive intestinal polypeptide (VIP) containing neurons in the hypothalamus of Japanese quail, Coturnix coturnix. Cell Tissue Res 226: 13-26.

4. Macnamee MC, Sharp PJ, Lea RW, Sterling RJ, Harvey S (1986) Evidence that vasoactive intestinal polypeptide is a physiological prolactin-releasing factor in the bantam hen. Gen Comp Endocrinol 62: 470-478.

5. Peczely P, Kiss JZ (1988) Immunoreactivity to vasoactive intestinal polypeptide (VIP) and tyrotropin releasing hormone (TRH) in hypothalamic neurons of the domesticated pigeon Columba livia alterations following lactation and exposure to cold. Cell Tissue Res 251: 485-494.

6. Mauro LJ, Elde RP, El Halawani ME (1988) Evidence of a differential expression of hypothalamic VIP immunoreactivity (VIP-IR) associated with prolactin (PRL) levels in the domestic turkey hen. Endocrinology 122 (Suppl 1): 133.

7. Robberecht P, De Neef P, Lammens M, DeshodtLanckman M, Christophe JP (1978) Specific binding of vasoactive intestinal peptide to brain membranes from the guinea pig. Eur J Biochem 90: 147-154.

8. Taylor DC, Pert CB (1979) Vasoactive intestinal polypeptide: specific binding to rat brain membranes. Proc Natl Acad Sci USA 76: 660-664.

9. Staun-Olsen P, Ottesen B, Bartels PD, Nielsen MH, Gammeltoft S, Fahrenkrug J (1982) Receptors for vasoactive intestinal polypeptide on isolated synaptosomes from rat cerebral cortex. Heterogeneity of binding and desensitization of receptors. $J$ Neurochem 39: 1242-1251.

10. Takahashi T, Kawashima M, Kamiyoshi M, Tanaka K (1992) Arginine vasotocin binding component in the uterus (shell gland) of the chicken. Acta Endocrinol 127: 179-184.

11. Rorstad OP, Wanke I, Coy DH, Fournier A, Huang M (1990) Selectivity for binding of peptide analogs to vascular receptors for vasoactive intestinal peptide. Mol Pharm 37: 971-977.

12. Lowry OH, Rosebrough NJ, Farr AL, Randall RJ (1951) Protein measurement with the folin phenol reagent. J Biol Chem 193: 265-275.

13. Bruns RF, Lawson-Wending K, Pugsley TA (1983) A rapid filtration assay for soluble receptors using polyethylenimine-treated filters. Anal Biochem 132: 74-81.

14. Scatchard G (1949) The attractions of proteins for small molecules and ions. Ann NY Acad Sci 51: 660-672.

15. Bylund DB, Yamamura HI (1990) Methods for receptor binding. In: Yamamura HI, Enna SJ, Kuhar MJ (eds) Methods in Neurotransmitter Receptor Analysis. Raven Press, New York: 1-35.

16. Snedecor GW (1956) Two or more random samples of measurement data. In: Snedecor GW (ed) Statistical Methods, 5th ed. The Iowa State University Press, Ames, IA, USA: 237-290.

17. Griffiths NM, Simmons NL (1990) Localization and characterization of functional vasoactive intestinal peptide receptors in feline kidney. Pflugers Arch 416: 80-87.

18. Meunier AC, Voisin P, Van Camp G, Cenatiempo Y, Muller JM (1991) Molecular characterization and peptide specificity of two vasoactive intestinal peptide (VIP) binding sites in the chicken pineal. Neuropeptides 19: 1-8.

19. Rozenboim I, El Halawani ME (1993) Characterization of vasoactive intestinal peptide pituitary membrane receptors in turkey hens during different stages of reproduction. Biol Reprod 48: 1129-1134.

20. Wanke IE, Rorstad OP (1990) Receptors for vasoactive intestinal peptide in rat anterior pituitary glands: localization of binding to lactotropes. Endocrinology 126: 1981-1988.

21. Kaku K, Inoue Y, Matsutani A, Okubo M, Hatao K, 
Kaneko T, Yanaihara N (1983) Receptors for vasoactive intestinal polypeptide on rat dispersed pineal cells. Biomed Res 4: 321-328.

22. Huang M, Rorstad OP (1990) PHI preferentially binds to VIP receptors in normal rat tissues. Peptides 11: 1015-1020.

23. Lacey CB, Elde RP, Seybold VS (1991) Localization of vasoactive intestinal peptide binding sites in the thymus and bursa of fabricius of the chick. Peptides 12: 383-391.

24. Enjalbert A, Arancibia S, Ruberg M, Priam M, BluetPajot MT, Rotsztejn WH, Kordon C (1980) Stimulation of in vitro prolactin release by vasoactive intestinal peptide. Neuroendocrinology 31: 200-204.

25. El Halawani ME, Silsby JL, Mauro LJ (1990) Enhanced vasoactive intestinal peptide-induced prolactin secretion from anterior pituitary cells of incubating turkeys (Meleagris gallopavo). Gen Comp Endocrinol 80: 138-145.

26. Miyata A, Arimura A, Dahl RR, Minamino N, Uehara A, Jiang L, Culler M, Coy DH (1989) Isolation of a novel 38 residue-hypothalamic polypeptide which stimulates adenylate cyclase in pituitary cells.
Biochem Biophys Res Commun 164: 567-574.

27. Gottschall PE, Tatsuno I, Miyata A, Arimura A (1990) Characterization and distribution of binding sites for the hypothalamic peptide, pituitary adenylate cyclase-activating polypeptide. Endocrinology 127: 272-277.

28. Ohtaki T, Watanabe T, Ishibashi $Y$, Kitada C, Tsuda M, Gottschall PE, Arimura A, Fujino M (1990) Molecular identification of receptor for pituitary adenylate cyclase activating polypeptide. Biochem Biophys Res Commun 171: 838-844.

29. Muller JM, El Battari A, Ah-Kye E, Luis J, Ducret F, Pichon J, Marvaldi J (1985) Internalization of the vasoactive intestinal peptide (VIP) in a human adenocarcinoma cell line (HT29). Eur J Biochem 152: 107-114.

30. Phillis JW, Kirkpatrick JR, Said SI (1978) Vasoactive intestinal polypeptide excitation of cerebral neurons. Can J Physiol Pharmacol 56: 337-340.

31. Deschodt-Lanckman M, Robberecht $P$, Christophe JP (1977) Characterization of VIP-sensitive adenylate cyclase on guinea pig brain. Fed Exp Biol Sci Lett 83: 76-80. 